\title{
Rate of Iceland Sea acidification from time series measurements
}

\author{
J. Olafsson ${ }^{1,2}$, S. R. Olafsdottir ${ }^{1}$, A. Benoit-Cattin ${ }^{1}$, M. Danielsen ${ }^{1}$, T. S. Arnarson ${ }^{1,3}$, and T. Takahashi ${ }^{4}$ \\ ${ }^{1}$ Marine Research Institute, Skulagata 4, IS 121 Reykjavik, Iceland \\ ${ }^{2}$ Institute of Earth Sciences, University of Iceland, Sturlugata 7, IS 101 Reykjavik, Iceland \\ ${ }^{3}$ National Energy Authority of Iceland, Grensasvegur 9, 108 Reykjavík, Iceland \\ ${ }^{4}$ Lamont-Doherty Earth Observatory of Columbia University, Palisades, NY 10964, USA
}

Received: 9 April 2009 - Published in Biogeosciences Discuss.: 26 May 2009

Revised: 10 November 2009 - Accepted: 13 November 2009 - Published: 25 November 2009

\begin{abstract}
The Iceland Sea is one part of the Nordic Seas. Cold Arctic Water prevails there and the deep-water is an important source of North Atlantic Deep Water. We have evaluated time series observations of measured $p \mathrm{CO}_{2}$ and total $\mathrm{CO}_{2}$ concentration from discrete seawater samples during 1985-2008 for the surface and 1994-2008 for deep-water, and following changes in response to increasing atmospheric carbon dioxide. The surface $\mathrm{pH}$ in winter decreases at a rate of $0.0024 \mathrm{yr}^{-1}$, which is $50 \%$ faster than average yearly rates at two subtropical time series stations, BATS and ESTOC. In the deep-water regime $(>1500 \mathrm{~m})$, the rate of $\mathrm{pH}$ decline is a quarter of that observed in surface waters. The surface seawater carbonate saturation states $(\Omega)$ are about 1.5 for aragonite and 2.5 for calcite, about half of levels found in subtropical surface waters. During 1985-2008, the degree of saturation $(\Omega)$ decreased at an average rate of $0.0072 \mathrm{yr}^{-1}$ for aragonite and $0.012 \mathrm{yr}^{-1}$ for calcite. The aragonite saturation horizon is currently at $1710 \mathrm{~m}$ and shoaling at $4 \mathrm{~m} \mathrm{yr}^{-1}$. Based on this rate of shoaling and on the local hypsography, each year another $800 \mathrm{~km}^{2}$ of seafloor becomes exposed to waters that have become undersaturated with respect to aragonite.
\end{abstract}

\section{Introduction}

The Nordic Seas lie north of the Greenland-Iceland-FaroesScotland Ridge, from which flows dense, cold overflow water to the North Atlantic (Hansen et al., 2008). The overflow waters are an important source for the global thermohaline circulation. The Iceland Sea is a constituent of the Nordic Seas. It is located north of Iceland and divided by the Kolbeinsey Ridge into two basins, the western part being shallower

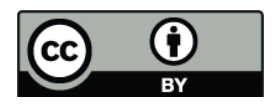

Correspondence to: J. Olafsson (jon@hafro.is)
(Fig. 1) (Jakobsson et al., 2008). The seafloor areas, depth and volumes, or hypsography, of the Nordic Seas has been described by Jakobsson (2002).

The hydrographic properties of the Iceland Sea can in essence be described as Arctic Intermediate Waters overlying Arctic Deep Water (Swift et al., 1980; Stefánsson, 1962). A time series of surface carbon chemistry observations was initiated in 1983 and includes temperature, salinity, $p \mathrm{CO}_{2}$ and the concentrations of total $\mathrm{CO}_{2}$ and macro-nutrients (Takahashi et al., 1985), Here we describe 21 years of wintermonth observations made during 1985-2008. The time series station is at $68.0^{\circ} \mathrm{N}, 12.67^{\circ} \mathrm{W}$ and has a bottom depth of $1850 \mathrm{~m}$ (Fig. 1). In midwinter, temperature and salinity profiles generally display a relatively thin surface mixed layer (Olafsson, 2003) and gentle variations with depth, with smooth transitions from intermediate to deep water (Fig. 2). These observations provide a basis for evaluating carbon chemistry changes that result from shifts in chemical equilibria as the level of atmospheric $\mathrm{CO}_{2}$ rises due to anthropogenic emissions of this gas.

There is increasing concern about the consequences of ocean acidification from the $\mathrm{CO}_{2}$ driven shifts toward lower seawater $\mathrm{pH}$ and $\mathrm{CaCO}_{3}$ saturation states, e.g. Royal Society (2005). Reactions involve firstly the hydrolysis of dissolved $\mathrm{CO}_{2}$, which increases the $\mathrm{H}^{+}$concentration and thus lowers $\mathrm{pH}$ :

$$
\mathrm{CO}_{2(\mathrm{aq})}+\mathrm{H}_{2} \mathrm{O} \rightarrow \mathrm{H}^{+}+\mathrm{HCO}_{3}^{-}
$$

Secondly, $\mathrm{H}^{+}$titrates the seawater carbonate and converts it to bicarbonate:

$$
\mathrm{H}^{+}+\mathrm{CO}_{3}^{2-} \rightarrow \mathrm{HCO}_{3}^{-}
$$

As the carbonate ion concentration is lowered, the dissolution of calcium carbonate $\mathrm{CaCO}_{3}$ increases:

$$
\mathrm{CaCO}_{3(\mathrm{~s})} \rightarrow \mathrm{Ca}^{2+}+\mathrm{CO}_{3}^{2-}
$$

Published by Copernicus Publications on behalf of the European Geosciences Union. 


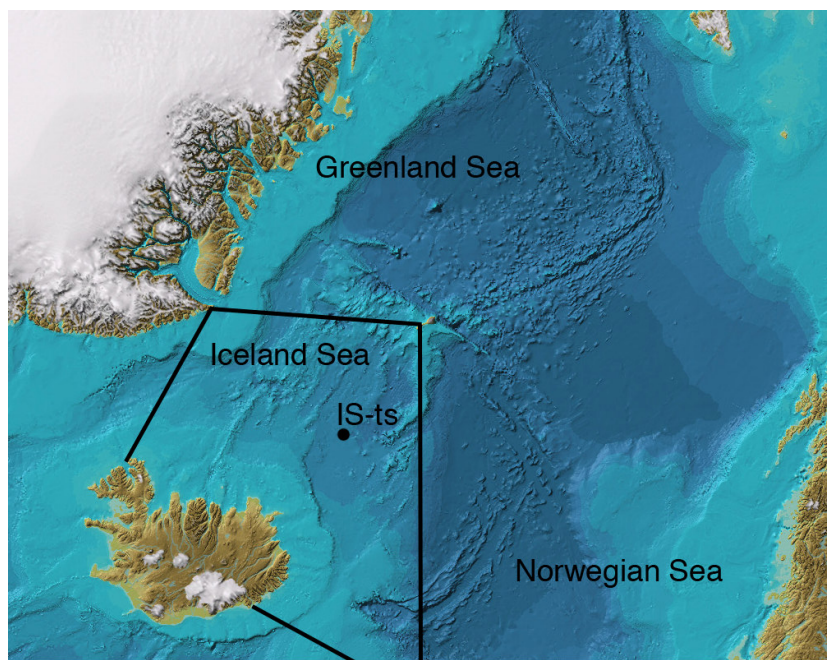

Fig. 1. Portion of the IBCAO v.2 bathymetric chart (Jakobsson et al., 2008) showing the Iceland Sea time series station, IS-ts, and adjacent Nordic Seas. The Iceland Sea boundaries are based on Jakobsson (2002).

The solubility product for calcium carbonate is written as

$\mathrm{Ksp}=\left[\mathrm{Ca}^{2+}\right]_{\text {sat }}\left[\mathrm{CO}_{3}^{2-}\right]_{\text {sat }}$

when seawater is at saturation with respect to a calcium carbonate mineral phase. The saturation state of calcium carbonate is:

$\Omega=\left[\mathrm{Ca}^{2+}\right]_{\mathrm{sw}}\left[\mathrm{CO}_{3}^{2-}\right]_{\mathrm{sw}} / \mathrm{Ksp}$

$\Omega=\left[\mathrm{CO}_{3}^{2-}\right]_{\mathrm{sw}} /\left[\mathrm{CO}_{3}^{2-}\right]_{\mathrm{sat}}$

where $\left[\mathrm{Ca}^{2+}\right]_{\mathrm{sw}}=\left[\mathrm{Ca}^{2+}\right]_{\mathrm{sat}}$

and the subscripts "sw" and "sat" refer to the in situ seawater concentration and the concentration at saturation, respectively. When $\Omega$ is $>1.0$ seawater is supersaturated; when $\Omega$ is $<1$ seawater is undersaturated. As the solubility product of the different mineral phases of $\mathrm{CaCO}_{3}$ differ, so does $\Omega$. The solubility product is higher for aragonite than for calcite. Consequently aragonite forming organisms may be more susceptible to the decrease in $\left[\mathrm{CO}_{3}^{2-}\right]$ resulting from addition of anthropogenic $\mathrm{CO}_{2}$ (Kleypas et al., 2006; Andersson et al., 2008).

The effect of increasing $\mathrm{CO}_{2}$ and decreasing $\mathrm{pH}$ in seawater on the corresponding $\Omega$ field in the oceans has been observed (Feely et al., 2004). Substantial impact is anticipated in high-latitude oceans by late this century as assessed by Orr et al. (2005) using ocean-carbon models. Recently another ocean-carbon-climate model study has indicated that the largest $\mathrm{pH}$ changes in this century would be seen in the surface waters of the Arctic Ocean (Steinacher et al., 2009). Concurrently, aragonite undersaturation might occur locally and become widespread as atmospheric $\mathrm{CO}_{2}$ increases to more than $450 \mathrm{ppm}$. Observations show that currently the aragonite saturation horizon in the deep Arctic Ocean is at

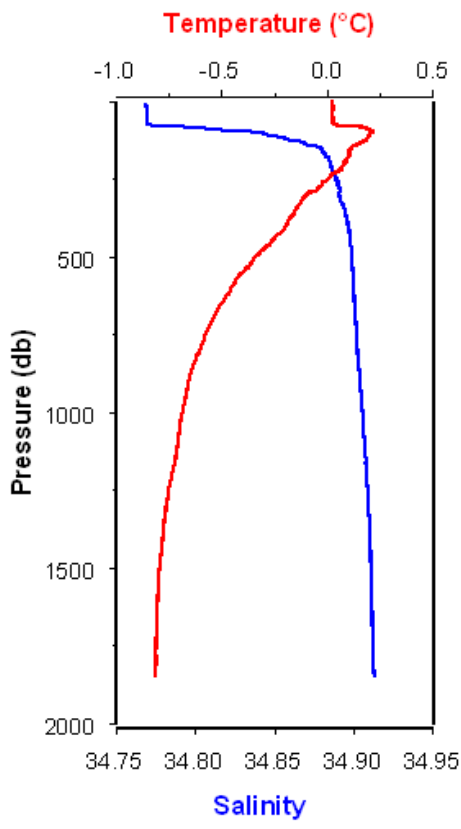

Fig. 2. Winter 2006 profiles of temperature and salinity at the time series station, IS-TS, showing a 90-m seasonal mixed layer and homogenous layer below $1500 \mathrm{~m}$ depth.

about $2500 \mathrm{~m}$ (Jutterström and Anderson, 2005). In this paper, we will focus on the Iceland Sea, in the southern part of the Nordic Seas, and assess the rate of surface- and deepwater acidification from time series measurements.

\section{Methods}

\subsection{Data}

The Iceland Sea time series data are in the CARINA data collection (Key et al., 2009). The time series data observations were made at quarterly intervals, generally in February, May, August and November (Olafsson et al., 2009). Deepwater carbon chemistry observations are available only since 1994. For the evaluation of long-term surface variations, we use winter observations 1985-2008, from the upper $20 \mathrm{~m}$ and collected during the first 67 days of the year (25 January to 7 March) in order to minimize the effects due to biological activity. In midwinter, daytime is short and convective cooling of the surface layer is intense while biological activity is at its annual minimum. However, the winter mixed layer depth generally extends to only about $200 \mathrm{~m}$ at the Iceland Sea time series station (Olafsson, 2003). A full description is presented elsewhere, both for the methods and the quality control measures taken when assembling the time series (Olafsson et al., 2009). For atmospheric $\mathrm{CO}_{2}$ near Iceland, we use Globalview data from Vestmannaeyjar, ICE_01D0 (GLOBALVIEW-CO2, 2009). Fig. 4 was prepared using ODV (Schlitzer, 2009). 


\subsection{Data processing and interpretation framework}

In our study, we chose to measure $p \mathrm{CO}_{2}$ by gas chromatography and $T \mathrm{CO}_{2}\left(=\left[\mathrm{CO}_{2}\right]_{\mathrm{aq}}+\left[\mathrm{HCO}_{3}^{-}\right]+\left[\mathrm{CO}_{3}^{2-}\right]\right)$ by coulometry (Chipman et al., 1993; Olafsson et al., 2009). This approach has two advantages. First, both the $p \mathrm{CO}_{2}$ and $T \mathrm{CO}_{2}$ are measured using common standards that are calibrated using the volumetric $\mathrm{CO}_{2}$ method maintained earlier by the late C. D. Keeling and presently by P. Tans of ESRL, US NOAA. Second, using these two properties, $\mathrm{pH}$ and $\left[\mathrm{CO}_{3}^{2-}\right]$ in seawater may be computed using the $\mathrm{CO}_{2}$ solubility and the first and second apparent dissociation constants for carbonic acid in seawater without the need for concentrations and dissociation constants of other acid species such as boric, phosphoric, silicic acids. The precision of our $p \mathrm{CO}_{2}$ and $T \mathrm{CO}_{2}$ measurements is $\pm 3 \mu \mathrm{atm}$ and $\pm 2 \mu \mathrm{mol} \mathrm{kg}^{-1}$ respectively. Accordingly, if the dissociation constants and solubility product of $\mathrm{CaCO}_{3}$ are assumed to be known exactly, the precisions for the computed quantities should be $\pm 1 \mu \mathrm{mol} \mathrm{kg}-1$ for $\left[\mathrm{CO}_{3}^{2-}\right], \pm 0.004$ for $\mathrm{pH}$ and \pm 0.02 for $\Omega$. However, $\pm 5 \%$ uncertainties in the dissociation constants for carbonic acid would cause an uncertainty of $\pm 5 \mu \mathrm{mol} \mathrm{kg}^{-1}$ in $\left[\mathrm{CO}_{3}^{2-}\right]$ and \pm 0.02 in $\mathrm{pH}$. Furthermore, $\pm 10 \%$ uncertainty in the solubility product of $\mathrm{CaCO}_{3}$ results in \pm 0.25 uncertainty in $\Omega$. Therefore, when the values reported in this paper are compared with results obtained using other sets of dissociation constants, these levels of uncertainty must be taken into consideration.

The $p \mathrm{CO}_{2}$ values in samples were measured at known equilibration temperature and barometric pressure, and results were corrected to in situ temperatures using the temperature coefficient of $0.0423^{\circ} \mathrm{C}^{-1}$ (Takahashi et al., 1993). From the observed $p \mathrm{CO}_{2}$ and $T \mathrm{TO}_{2}$ results, we calculate $\mathrm{pH}$ (total scale) and calcium carbonate saturation at $1 \mathrm{~atm}$ pressure using the CO2SYS software (Lewis and Wallace, 1998), the solubility of $\mathrm{CO}_{2}$ in seawater by (Weiss, 1974) and the apparent dissociation constants for carbonic acid of Mehrbach et al. (1973) as refit by Dickson and Millero (1987). The CO2SYS software also calculates $\mathrm{pH}$, $\left[\mathrm{CO}_{3}^{2-}\right]$, aragonite and calcite saturation states from their solubility products Ksp (Mucci, 1983) at in-situ pressure, temperature and salinity. For documenting long-term changes in the ocean chemistry, one needs a precise analytical method accompanied by well defined and stable standards for instrument calibration. Although direct measurements of $\mathrm{pH}$ or $\mathrm{H}^{+}$ion concentration in seawater are desirable, commonly used electrode methods suffer from ambiguities in regards to whether measurements represent $\mathrm{H}^{+}$ion activities, concentrations, or the sum of concentrations of $\mathrm{H}^{+}$species involved in acid-base reactions. Additionally, intercomparison of measurements made using different electrode systems is difficult because electrode liquid-junction potentials vary among calibration solutions, such as those used for the NBS scale (Bates, 1973) and those used for seawater (Bates and Culberson, 1977). Another parameter, total (or titration) alkalinity, may be determined precisely and reproducibly using calibrated $\mathrm{HCl}$ solutions. However, alkalinity is a statement of the neutrality of ionic charges, and consists of contributions from various acids including carbonic, boric, silicic, phosphoric and some organic acids. In principle, exact computation of $\mathrm{pH}$ using the alkalinity requires a precise understanding of these component acids, including their concentrations and dissociation constants. However, the concentrations of the nutrient salts are generally low in the northern waters, and hence neglecting the contributions of phosphoric and silicic acids from alkalinity introduces only small systematic errors in computed chemical parameters. A typical winter surface water in the Iceland Sea has the following properties; $\mathrm{SST}=-0.19^{\circ} \mathrm{C}$, salinity $=34.7$, total alkalinity $=2285 \mu \mathrm{eq} \mathrm{kg}^{-1}, T \mathrm{CO}_{2}=2150 \mu \mathrm{mol} \mathrm{kg}^{-1}$ with about $4 \mu \mathrm{mol} \mathrm{kg}^{-1}$ for silicate and $0.7 \mu \mathrm{mol} \mathrm{kg}{ }^{-1}$ for phosphate. If silicate and phosphate are neglected, the resulting properties in seawater would yield the $p \mathrm{CO}_{2}$ value too low by $2 \mu \mathrm{atm}, \mathrm{pH}$ value too high by 0.002 , and $\Omega$ value too high by 0.01 . Therefore, systematic errors introduced by neglecting nutrients in the $\mathrm{CO} 2$-system calculations are within the experimental errors for the alkalinity $\left( \pm 3 \mu \mathrm{eq} \mathrm{kg}{ }^{-1}\right)$ and $T \mathrm{CO}_{2}$ $\left( \pm 2 \mu \mathrm{mol} \mathrm{kg}^{-1}\right)$ and would not affect our computed trends. On the other hand, in high nutrient waters such as those found in the Southern Ocean (silicate $>100 \mu \mathrm{mol} \mathrm{kg}^{-1}$ ), the systematic errors may be as large as $-10 \mu \mathrm{atm}$ in $p \mathrm{CO}_{2},+0.01$ in $\mathrm{pH}$ and +0.05 in $\Omega$.

\section{Results}

\subsection{Surface changes}

Over the 23-year period of the surface-water time series, 1985-2008, the temperature of water changed as well as $p \mathrm{CO}_{2}, T \mathrm{TO}_{2}, \mathrm{pH}$ and $\Omega$ (Fig. 3). Accordingly, the results are analysed using a linear multivariate regression using temperature and time as independent variables, so that the effect of temperature change on $p \mathrm{CO}_{2}, T \mathrm{CO}_{2}, \mathrm{pH}$ and $\Omega$ may be differentiated from the time trend. The measured surface layer $p \mathrm{CO}_{2}$ increases at a rate of $2.1 \pm 0.2 \mu \mathrm{atm} \mathrm{yr}^{-1}$ (Fig. 3, Table 1). This trend of surface ocean $p \mathrm{CO}_{2}$ increase is greater than that of the atmosphere in the same winter period, $1.69 \pm 0.04 \mathrm{ppm} \mathrm{yr}^{-1}$, and indicates a decrease in the air-sea $p \mathrm{CO}_{2}$ difference, the thermodynamic driving force of the air-sea $\mathrm{CO}_{2}$ flux. Similar trends have been reported for the N. Atlantic (Schuster et al., 2009; Schuster and Watson, 2007) and the Nordic Seas (Olsen et al., 2006). In response to the increasing $p \mathrm{CO}_{2}$, the computed surface seawater $\mathrm{pH}$ values reveal a strong decreasing trend (Fig. 3). Table 1 shows that the $\mathrm{pH}$ declines by $-0.0024 \mathrm{yr}^{-1}$ and the $\left[\mathrm{H}^{+}\right]$increases by $14 \%$ over the 23 -year period. For comparison, at two subtropical Atlantic time-series stations, BATS near Bermuda and ESTOC near the Canary Islands, the observed rate of surface seawater $\mathrm{pH}$ decline is slower, 
Table 1. Iceland Sea trends of surface-water $p \mathrm{CO}_{2}, \mathrm{pH}$, and saturation states for aragonite and calcite based on a multivariate linear regression $y=a t+b T+c$, where $t$ is time (year between 1985 and 2008) and $T$ is temperature $\left({ }^{\circ} \mathrm{C}\right.$ ), and $a, b$, and $c$ are constants.

\begin{tabular}{lccccc}
\hline$y$ & $a$ & $b$ & $c$ & $r^{2}$ & $\mathrm{~N}$ \\
\hline$p \mathrm{CO}_{2}$ winter & $2.145 \pm 0.157$ & $-2.888 \pm 2.230$ & 314.27 & 0.920 & 21 \\
$T \mathrm{CO}_{2}$ & $1.44 \pm 0.23$ & $-6.63 \pm 3.25$ & -739.54 & 0.678 & 22 \\
$\mathrm{pH}$ winter & $-0.0024 \pm 0.0002$ & $0.0056 \pm 0.0027$ & $13.00 \pm 0.38$ & 0.907 & 21 \\
$\mathrm{pH}$ all seasons & $-0.002 \pm 0.005$ & $0.0063 \pm 0.0011$ & $11.95 \pm 0.96$ & 0.380 & 78 \\
$\mathrm{pH}$ summer & $-0.0017 \pm 0.0009$ & $0.0037 \pm 0.0018$ & $11.60 \pm 1.77$ & 0.182 & 39 \\
$\Omega_{\mathrm{ar}}$ winter & $-0.0072 \pm 0.0007$ & $0.0778 \pm 0.0094$ & $15.97 \pm 1.33$ & 0.882 & 21 \\
$\Omega_{\mathrm{ca}}$ winter & $-0.0117 \pm 0.0011$ & $0.121 \pm 0.015$ & $25.78 \pm 2.13$ & 0.882 & 21 \\
\hline
\end{tabular}
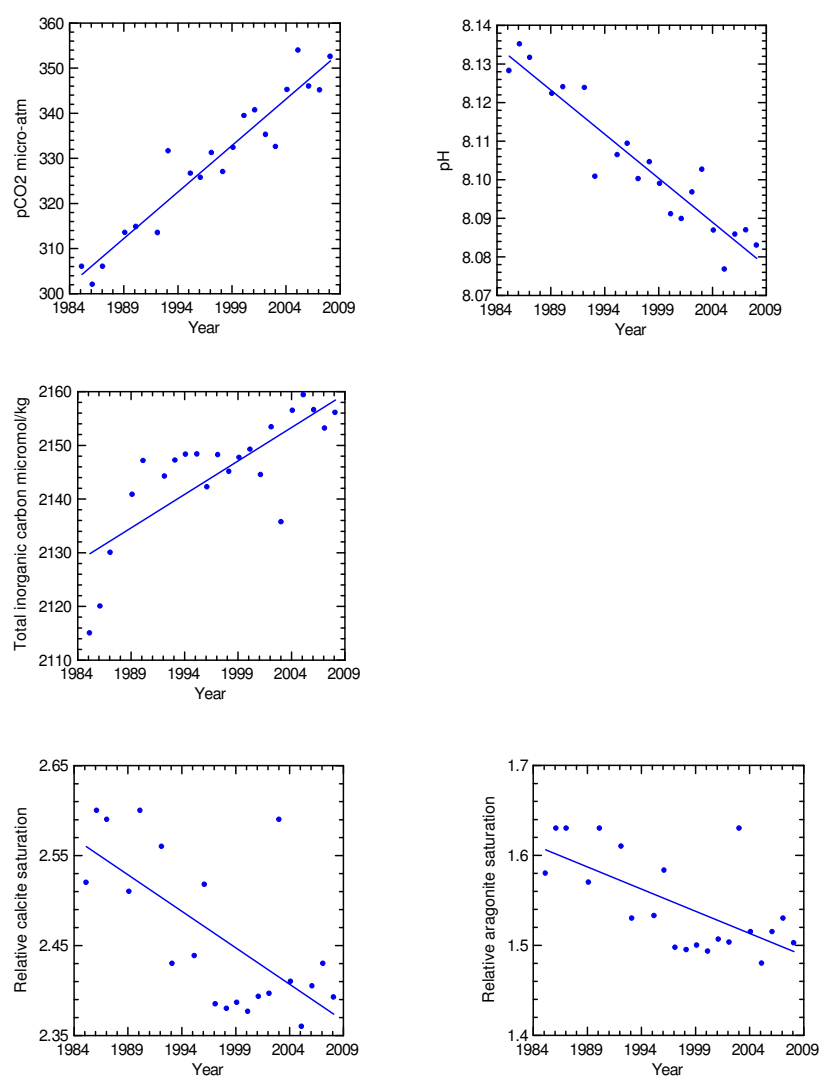

Fig. 3. Iceland Sea winter surface water changes in $p \mathrm{CO}_{2}, \mathrm{pH}$ (total scale), total dissolved inorganic carbon, and the saturation states of aragonite and calcite $\left(\Omega_{\mathrm{ar}}\right.$ and $\left.\Omega_{\mathrm{ca}}\right)$. Coefficients for multivariate linear regression lines are shown in Table 1 .

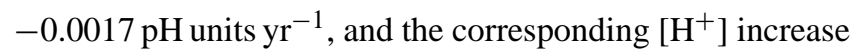
9\% smaller compared to the Iceland Sea (Bates, 2007; Santana-Casiano et al., 2007). However, our rates are not directly comparable with those from BATS, which are based on seasonally-detrended whole-year data, nor with rates at ESTOC, which are based on a multivariate regression of wholeyear data. The temperature effect $0.0056^{\circ} \mathrm{C}^{-1}$ computed from regression analysis (Table 1) is larger than expected from the observed hydrographic temperature trend, suggesting that it includes variations in other parameters, e.g. $T \mathrm{CO}_{2}$, which influences $\mathrm{pH}$. Addition of $T \mathrm{CO}_{2}$ as another variable to the multivariate linear regression reduces the temperature coefficient to $0.0045^{\circ} \mathrm{C}^{-1}$ but changes the $\mathrm{pH}$ rate by only

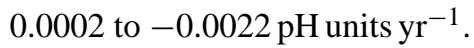

In this cold water with a mean temperature of $-0.3^{\circ} \mathrm{C}$, the saturation states, $\Omega_{\mathrm{ar}}$ and $\Omega_{\mathrm{ca}}$, are low, and they have decreased over the observation period (Fig. 3 and Table 1). The time rates of change of Omega are comparable with those observed at BATS (Bates, 2007). The $\Omega_{\mathrm{ca}}$ is decreasing at a rate about 1.6 times faster than that of $\Omega_{\text {ar }}$ (Table 1), as expected from the ratio of solubility products at $2^{\circ} \mathrm{C}$. That is, since $\Omega$ is inversely proportional to Ksp as shown in Reaction (R5), the rate of change in $\Omega$ reflects the Ksp of these minerals: for a given change in $\left[\mathrm{CO}_{3}^{2-}\right]$ resulting from a $\mathrm{pH}$ change, $\Omega_{(\text {calcite })} / \Omega_{(\text {aragonite })}=\mathrm{Ksp}_{(\text {aragonite })} / \mathrm{Ksp}_{(\text {calcite })}=1.6$.

\subsection{Deep-water changes}

We evaluate the changes in deep-water carbonate chemistry from all observations below $500 \mathrm{~m}$ where seasonal variability is negligible. It is evident from the water column investigations during 1994-2008 (Fig. 4) that $\mathrm{pH}$ and the carbonate saturation states of aragonite and calcite are decreasing; isolines are shoaling with time. Over the duration of the observations, the aragonite saturation horizon, $\Omega_{\mathrm{ar}}=1$, shoals from $1763 \mathrm{~m}$ to $1710 \mathrm{~m}$. For the deepest water, the time rate of change in the carbonate system parameters was evaluated from 97 samples from the 1500-1850 $\mathrm{m}$ depth range. In deep waters, the temperature is nearly constant, while the solubility product of calcium carbonate depends on the water depth (or pressure). Therefore, pressure and time are chosen as independent variables in a multivariate linear regression in order to differentiate the time trend from the pressure effect (Table 2). The pressure effects thus obtained are compared with the measured pressure effect on $\mathrm{Ksp}$ of $-\Delta \mathrm{V}\left(\mathrm{cm}^{3}\right)=36.00-0.20 \times\left(\mathrm{T}^{\circ} \mathrm{C}\right)$ for calcite and $-\Delta \mathrm{V}\left(\mathrm{cm}^{3}\right)=33.3-0.22 \times\left(\mathrm{T}^{\circ} \mathrm{C}\right)$ for aragonite (Mucci, 1983). These pressure effects correspond to $-5.0 \times 10^{-5} \mathrm{db}^{-1}$ for $\mathrm{pH},-3.4 \times 10^{-4} \mathrm{db}^{-1}$ for $\Omega_{\mathrm{ca}}$ and 
Table 2. Iceland Sea trends of deep-water $\mathrm{pH}$ and saturation states for aragonite and calcite based on a multivariate linear regression $y=a t+b P+c$, where $t$ is time (year between 1994 and 2008) and $P$ is pressure (db) for samples deeper than $1500 \mathrm{db}$, and $a, b$, and $c$ are constants.

\begin{tabular}{lccccc}
\hline$y$ & $a$ & $b$ & $c$ & $r^{2}$ & $\mathrm{~N}$ \\
\hline $\mathrm{pH}$ & $-0.0006 \pm 0.0001$ & $-0.000058 \pm 0.000004$ & $9.319 \pm 0.204$ & 0.767 & 97 \\
$\Omega_{\mathrm{ar}}$ & $-0.0009 \pm 0.0002$ & $-0.000251 \pm 0.000009$ & $3.333 \pm 0.478$ & 0.906 & 97 \\
$\Omega_{\mathrm{ca}}$ & $-0.0015 \pm 0.0004$ & $-0.000411 \pm 0.000013$ & $5.288 \pm 0.731$ & 0.916 & 97 \\
\hline
\end{tabular}

$-2.0 \times 10^{-4} \mathrm{db}^{-1}$ for $\Omega_{\mathrm{ar}}$ at the temperatures and pressures of deep waters in our study area. The results of the multivariate linear regression include the effects of pressure as well as other changes such as chemical compositions. Nevertheless, considering the uncertainties (up to $20 \%$ in $\Delta \mathrm{V}$, (Broecker and Takahashi, 1976)) in the pressure effect on the Ksp of calcite and aragonite, the results of our regression analysis $\left(-5.8 \times 10^{-5} \mathrm{db}^{-1}\right.$ for $\mathrm{pH} ;-4.0 \times 10^{-4} \mathrm{db}^{-1}$ for $\Omega_{\mathrm{ca}} ;-2.5 \times 10^{-4} \mathrm{db}^{-1}$ for $\left.\Omega_{\mathrm{ar}}\right)$ are consistent with the experimental values, thus giving credence to our method of analysis.

In this near bottom layer, the $\mathrm{pH}$ declines at a rate of $-0.0006 \mathrm{yr}^{-1}$ (Table 2), about 4 times slower than at the surface (Table 1). The corresponding increase in $\mathrm{H}^{+}$concentration over 23 years is $3.1 \%$ or about $1 / 4$ of the surface rate.

Similarly, below $1500 \mathrm{~m}$ the aragonite saturation state is

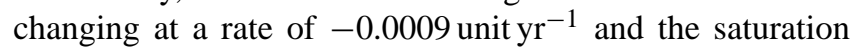
horizon is shoaling with time (Table 2). This rate of decline for $\Omega_{\mathrm{ar}}$ is $13 \%$ of that at the surface. The same applies to the $\Omega_{\mathrm{ca}}$ decline. The rate of shoaling of the aragonite saturation horizon (where $\Omega_{\mathrm{ar}}=1$ ) was evaluated using the regression coefficients in Table 2 and solving the multivariate linear regression for pressure when $\Omega_{\mathrm{ar}}=1$ for years 1995 and 2005 . Over this 10 -year period, the aragonite saturation hori-

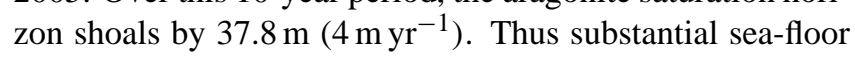
area may undergo a transition from supersaturated to undersaturated conditions as determined by the hypsometry of the Iceland Sea, which characterizes the basin by its relation between depth and sea-floor area.

The Iceland Sea is relatively shallow, the mean depth being $1026 \mathrm{~m}$, whereas the mean depths of the adjacent Norwegian and Greenland Seas are, respectively, $1816 \mathrm{~m}$ and $1580 \mathrm{~m}$ (Fig. 1) (Jakobsson, 2002). The aragonite saturation horizon $(\Omega=1)$ in the Iceland Sea is about $800 \mathrm{~m}$ shallower than in the Arctic where it is at about $2500 \mathrm{~m}$ (Jutterström and Anderson, 2005). The hypsometric curve for the Iceland Sea reveals a rather gentle slope between 1000 and $1800 \mathrm{~m}$, such that a 1-m depth change corresponds to $200 \mathrm{~km}^{2}$ of sea floor (Fig. 5). As the aragonite saturation horizon is currently shoaling at $4 \mathrm{~m} \mathrm{yr}^{-1}$, each year $800 \mathrm{~km}^{2}$ of the Iceland Sea floor along with associated biota become exposed to waters that have just become undersaturated with respect to aragonite. This analysis assumes similar temperature, salinity and
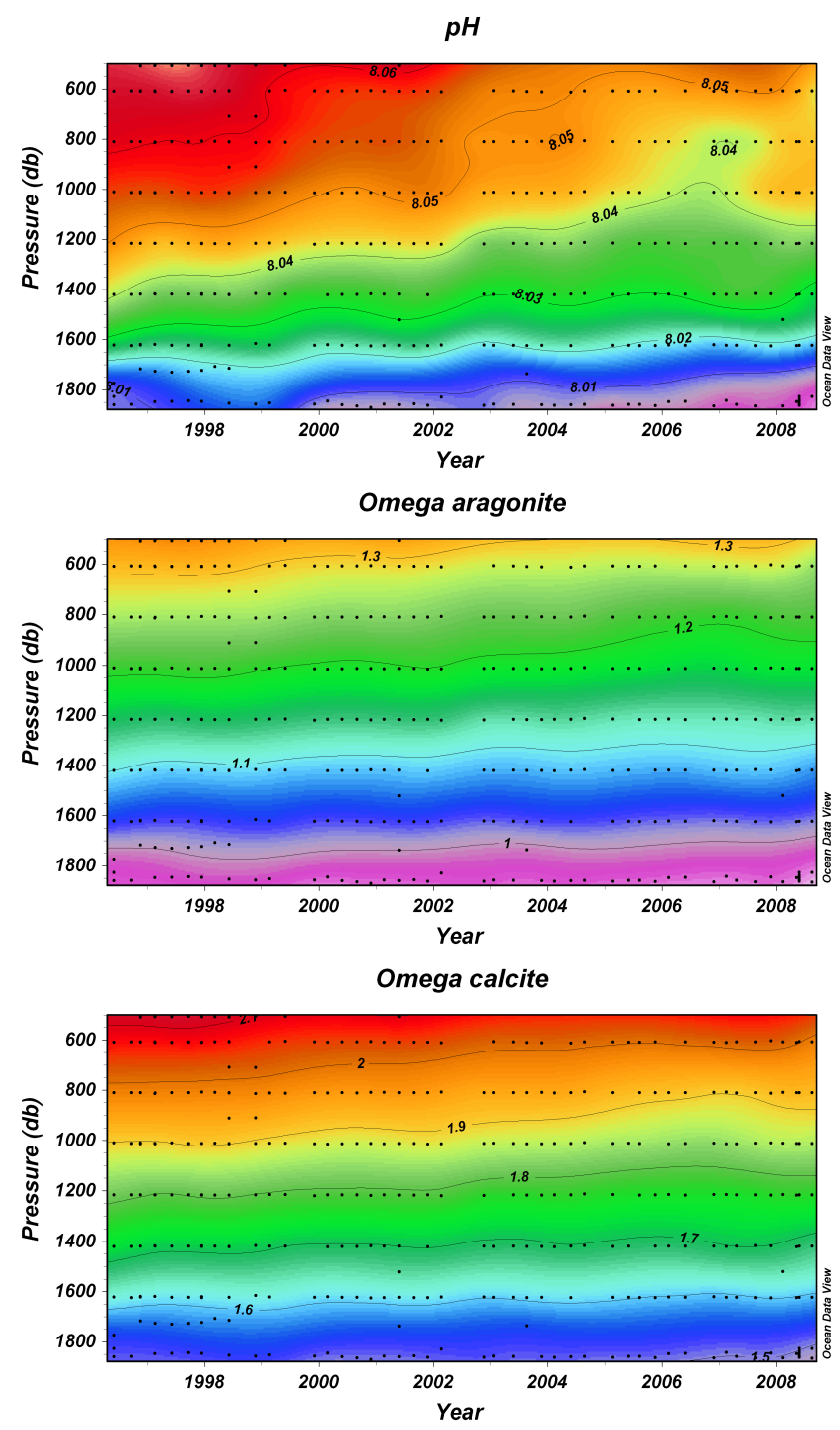

Fig. 4. Iceland Sea Time Series of deep-water trends during 19942008 for $\mathrm{pH}$, aragonite saturation and calcite saturation. The station depth is $1850 \mathrm{~m}$.

carbon chemistry properties within this depth range across the basin. Our data from both east and west of the Kolbeinsey Ridge, the latter being shallower, indicate that this assumption of homogeneity is valid (Table 3 ).

There are two major reasons why these changes in the Nordic Seas are faster than those in the subtropical Atlantic. 
Table 3. Iceland Sea mean properties of the seawater in the depth range 1000-1500 db west and east of the Kolbeinsey Ridge.

\begin{tabular}{ccccccccc}
\hline & Pressure & $t^{\circ} \mathrm{C}$ & $\mathrm{S}$ & $\begin{array}{c}\mathrm{TCO}_{2} \\
\mu \mathrm{mol} \mathrm{kg}^{-1}\end{array}$ & $\begin{array}{c}p \mathrm{CO}_{2} \\
\mu \mathrm{atm}\end{array}$ & $\Omega_{\mathrm{ar}}$ & $\Omega_{\mathrm{ca}}$ & $\mathrm{pH}$ \\
\hline Western basin & $1135 \pm 142$ & $-0.56 \pm 0.12$ & $34.898 \pm 0.042$ & $2161 \pm 4$ & $329 \pm 15$ & $1.18 \pm 0.06$ & $1.86 \pm 0.10$ & $8.052 \pm 0.019$ \\
Eastern basin & $1207 \pm 164$ & $-0.76 \pm 0.15$ & $34.908 \pm 0.006$ & $2166 \pm 5$ & $330 \pm 4$ & $1.17 \pm 0.05$ & $1.83 \pm 0.08$ & $8.049 \pm 0.009$ \\
\hline
\end{tabular}

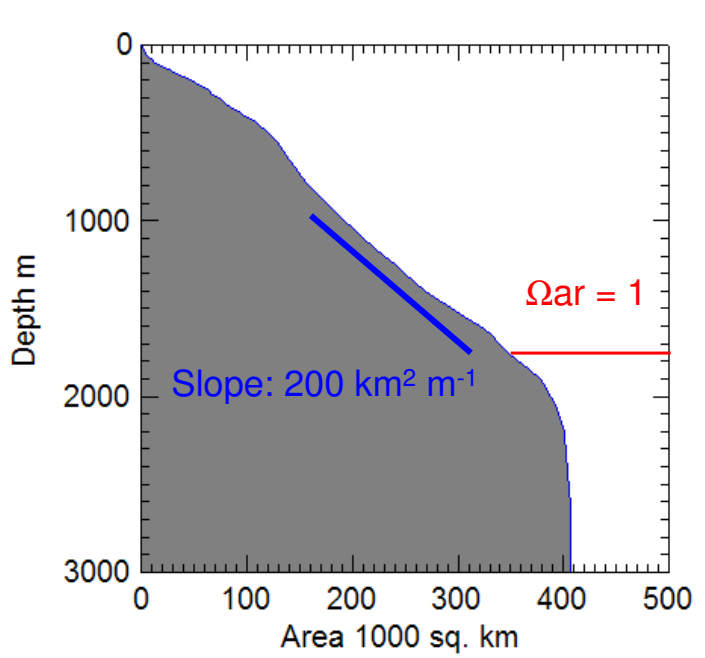

Fig. 5. The hypsometry of the Iceland Sea from Jakobsson (2002) shows that in the depth range 1000-1800 m, a 1-m shoaling of the aragonite saturation horizon results in $200 \mathrm{~km}^{2}$ of seafloor being exposed to bottom waters that are undersaturated with respect to aragonite.

First, the buffer capacity of the cold Arctic waters is less than that of subtropical waters. The Revelle factor in the Iceland Sea surface water in winter was about 15.2 in the early 2000, whereas in the subtropical Atlantic at BATS it was 9.2 (Bates, personal communication, 2009). Thus, for the same amount of $\mathrm{CO}_{2}$ added to seawater, reduction in $\mathrm{pH}$ would be greater in the Iceland Sea surface water. Second, Iceland Sea surface waters are undersaturated with respect to atmospheric $\mathrm{CO}_{2}$ throughout the year due to low temperatures and intense biological utilization. Hence the Iceland Sea absorbs more $\mathrm{CO}_{2}$ per unit area (Takahashi et al., 2002; Takahashi et al., 2009) as do the Nordic Seas in general (Skjelvan et al., 2005). The Iceland Sea's air-sea $\mathrm{CO}_{2}$ flux has been estimated to be about $4.5 \mathrm{~mol} \mathrm{~m}^{-2} \mathrm{yr}^{-1}$ (Olafsson et al., in preparation). Both its higher air-sea $\mathrm{CO}_{2}$ flux and its lower buffer capacity (higher Revelle factor) result in stronger acidification of Iceland Sea surface waters.

\section{Discussion}

The data used here includes observations not only from midwinter, our focus, but also from other seasons. In the Iceland Sea there is large seasonality in both physical and biogeochemical parameters, as described previously (Takahashi et al., 1985; Takahashi et al., 1993). In these papers, we reported that the seasonal variation in $p \mathrm{CO}_{2}$ is not sinusoidal but more like a saw-tooth shape with a maximum platform in midwinter and a sharp drop to the annual minimum caused by the phytoplankton spring bloom. The annual amplitude of surface $p \mathrm{CO}_{2}$ in our quarterly observations may reach $160 \mu \mathrm{atm}$, mostly depending on how close to the spring bloom the May observations are taken. The location and timing of the spring drawdown of $\mathrm{CO}_{2}$ varies due to the patchy nature of phytoplankton blooms. The $\mathrm{pH}$ values computed using the $p \mathrm{CO}_{2}$ and $T \mathrm{CO}_{2}$ data reflect these seasonal changes and show a similar pattern. Thus, the spring-summer $\mathrm{pH}$ values exhibit large space and time variability, and yield a mean-time trend with large uncertainties. In contrast, during midwinter, biological production is minimal due to short daytime and cold temperatures. Winter conditions are governed primarily by physical and abiological processes such as sea-air $\mathrm{CO}_{2}$ gas exchange and convective mixing of subsurface waters. Hence, the winter values for seawater $p \mathrm{CO}_{2}$ and $\mathrm{pH}$ exhibit much smaller variability, and a more reliable time trend can be obtained. The results in Table 1 on the winter observations show that $89 \%$ of the variability in the $\mathrm{pH}$ can be accounted for by time alone, and $92 \%$ can be accounted for by adding temperature to the regression. In contrast, if all the seasonal data are included in this statistical evaluation, the variability explained drops to $38 \%$, and when summer observations alone are are used it drops to $18 \%$ (Table 1). Thus the statistical evaluation of the time trends becomes uncertain when based on observations from all seasons. Our goal here is to describe the long-term changes in the seawater carbon chemistry due to increasing atmospheric $\mathrm{CO}_{2}$ and changing ocean circulation. Since surface waters in winter represent the initial conditions for seasonal modifications during the following year, the winter observations serve our purpose well. It is also clear that evaluation of long-term trends from whole year data has to be carried out with caution. Thus, let us recall that the subtropical ESTOC and BATS time series are located in the areas with smaller and smoother seasonal variations than the Iceland Sea time 
series, and they have monthly observations as opposed to the seasonal (quarterly) measurements in the Iceland Sea.

The trend in surface $\Omega_{\mathrm{ar}}$ and $\Omega_{\mathrm{ca}}$ (Fig. 3) is not as strongly related to time alone as is the case for surface water $p \mathrm{CO}_{2}$. Table 1 shows that a multivariate linear regression using the variables time and temperature can explain $88 \%$ of the variability in $\Omega_{\mathrm{ar}}$ and $\Omega_{\mathrm{ca}}$, whereas a linear regression based on time alone can only explain $46 \%$ of the variability. Unlike the case for oceanic $p \mathrm{CO}_{2}$, temperature variations substantially influence the trends in the saturation states and explain the apparent stability after 1997.

The shorter period of deep-water observations (19942008) relative to the surface layer observations (1985-2008) requires that we compare the latter during the shorter recent period. The surface water trend of $\Omega_{\mathrm{ar}}$ during 1994-2008 is $-0.006 \pm 0.001 \mathrm{yr}^{-1}$, which is not significantly different from $-0.007 \pm 0.0007 \mathrm{yr}^{-1}$ found for the period 1985-2008 (Table 1). The deep-water trend of $\Omega_{\mathrm{ar}}$ in the same period was $-0.0009 \pm 0.0002 \mathrm{yr}^{-1}$ (Table 2). Thus the shorter record from the relatively stable deep-water appears long enough to provide a meaningful comparison with the longer record from the more variable surface layer.

\section{Conclusions}

The anthropogenic increase of atmospheric carbon dioxide affects the Iceland Sea both at the surface and at depth. In the surface, the $\mathrm{pH}$ has decreased from 8.13 to 8.08 between 1985 and 2008 , and the aragonite saturation $(\Omega)$, which is naturally low anyway, decreased from 1.6 to 1.5 between 1985 and 2008. In the deep-water, the aragonite saturation horizon, currently at $1710 \mathrm{~m}$, is shoaling at a rate of about $4 \mathrm{~m} \mathrm{yr}^{-1}$. This shoaling results from extensive vertical mixing which transmits atmospheric signatures to waters as deep as $1500 \mathrm{~m}$ (Messias et al., 2008). Large areas of the benthos are thus undergoing a rapid transition from being exposed to waters that are supersaturated to being exposed to waters that are undersaturated with respect to aragonite. There is an urgent need to clarify the effects of these changes on associated benthic ecosystems, especially at shallower depths, where the population of carbonate forming benthic biota are much greater.

Acknowledgements. The authors thank all colleagues at the Marine Research Institute in Iceland, who have cooperated and assisted in the time series work in its course since 1983. This work is supported by the European Community Sixth Framework Programme CARBOOCEAN IP, Marine carbon sources and sinks assessment Contract no. 511176 and it is a contribution to the "European Project on Ocean Acidification" (EPOCA) which received funding from the European Community's Seventh Framework Programme (FP7/2007-2013) under grant agreement no. 211384. T. T. is supported by a grant (NAO30AR4320179P27) from US NOAA.

\section{References}

Andersson, A. J., Mackenzie, F. T., and Bates, N. R.: Life on the margin: Implications of ocean acidification on $\mathrm{Mg}$-calcite, high latittude and cold-water marine calcifiers, Mar. Ecol. Prog. Ser., 373, 265-273, doi:10.3354/meps07639, 2008.

Bates, N. R.: Interannual variability of the oceanic $\mathrm{CO}_{2}$ sink in the subtropical gyre of the North Atlantic Ocean over the last two decades, J. Geophys. Res., 112, C09013, doi:10.1029/2006JC003759, 2007.

Bates, R. G.: Determination of pH, 2nd Edn., John Wiley \& Sons, New York, 1973.

Bates, R. G. and Culberson, C. H.: Hydrogen ions and the thermodynamic state of marine systems, in: The Fate of Fossil Fuel $\mathrm{CO}_{2}$ in the Oceans, edited by: Andersen, N. R. and Malahoff, A., Plenum Press, New York, 45-61, 1977.

Broecker, W. S. and Takahashi, T.: The solubility of calcite in sea water, in: Thermodynamics in Geology, edited by: Fraser, D. G., D. Reidel Publ. Co., Boston, USA, 365-379, 1976.

Chipman, D., Marra, J., and Takahashi, T.: Primary production at $47^{\circ} \mathrm{N}$ and $20^{\circ} \mathrm{W}$ in the North Atlantic Ocean: a comparision between the ${ }^{14} \mathrm{C}$ incubation method and the mixed layer budget, Deep-Sea Res. Pt. II, 40, 151-169, 1993.

Dickson, A. G. and Millero, F. J.: A Comparison of the equilibrium constant for the dissociation of carbon acid in seawater media, Deep-Sea Res., 34, 1733-1743, 1987.

Feely, R. A., Sabine, C. L., Lee, K., Berelson, W., Kleypas, J., Fabry, V. J., and Millero, F. J.: Impact of Anthropogenic CO2 on the $\mathrm{CaCO} 3$ System in the Oceans, Science, 305, 362-366, 2004.

GLOBALVIEW-CO 2: Cooperative Atmospheric Data Integration Project - Carbon Dioxide, CD-ROM, NOAA GMD, Boulder, Colorado (Also available on Internet via anonymous FTP to ftp.cmdl.noaa.gov, Path: ccg/co2/GLOBALVIEW, 2009.

Hansen, B., Østerhus, S., Turrell, W. R., Jónsson, S., Valdimarsson, H., Hátún, H., and Olsen, S. M.: The inflow of Atlantic Water, heat and salt to the Nordic Seas across the Greenland-Scotland Ridge, in: Arctic-Subarctic Ocean Fluxes, edited by: Dickson, R. R., Meincke, J., and Rhines, P., Springer, Dordrecht, 15-43, 2008.

Jakobsson, M.: Hypsometry and volume of the Arctic Ocean and its constituent seas, Geochem. Geophys. Geosy., 3(5), 1028, doi:10.1029/2001GC000302, 2002.

Jakobsson, M., Macnab, R., Mayer, L., Anderson, R., Edwards, M., Hatzky, J., Schenke, H.-W., and Johnson, P.: An improved bathymetric portrayal of the Arctic Ocean: Implications for ocean modeling and geological, geophysical and oceanographic analyses, Geophys. Res. Lett., 35, L07602, doi:10.1029/2008GL033520, 2008.

Jutterström, S. and Anderson, L. G.: The saturation of calcite and aragonite in the Arctic Ocean, Mar. Chem., 94, 101-110, 2005.

Key, R. M., Tanhua, T., Olsen, A., Hoppema, M., Jutterström, S., Schirnick, C., Heuven, S. V., Kozyr, A., Lin, X., Velo, A., Wallace, D. W. R., and Mintrop, L.: The CARINA data synthesis project: Introduction and overview, Earth Syst. Sci. Data Discuss., in press, 2009.

Edited by: J. Orr 
Kleypas, J. A., Feely, R. A., Fabry, V. J., Langdon, C., Sabine, C. L., and Robbins, L. L.: Impacts of Ocean Acidification on Coral Reefs and Other Marine Calcifiers: A Guide for Future Research, NSF, NOAA, US Geological Survey, Report of a workshop, 88, 2006.

Lewis, E. and Wallace, D.: Programme developed for $\mathrm{CO}_{2}$ system calculations, Carbon Dioxide Information Analysis Center, Oak Ridge National Laboratory, US Department of Energy, ORNL/CDIAC-105, 1998.

Mehrbach, C., Culberson, C. H., Hawlay, J. E., and Pytkowicz, R. M.: Measurement of the apparent dissociation constants of carbonic acid in seawater at atmospheric pressure, Limnol. Oceanogr., 18, 897-907, 1973.

Messias, M.-J., Watson, A. J., Johannessen, T., Oliver, K. I. C., Olsson, K. A., Fogelqvist, E., Olafsson, J., Bacon, S., Balle, J., Bergman, N., Budéus, G., Danielsen, M., Gascard, J.-C., Jeansson, E., Olafsdottir, S. R., Simonsen, K., Tanhua, T., Scoy, K. V., and Ledwell, J. R.: The Greenland Sea tracer experiment 1996-2002: Horizontal mixing and transport of Greenland Sea Intermediate Water, Prog. Oceanogr., 78, 85-105, 2008.

Mucci, A.: The solubility of calcite and aragonite in sea water at various salinities, temperatures and one atmosphere total pressure, Am. J. Sci, 238, 780-799, 1983.

Olafsson, J.: Winter mixed layer nutrients in the Irminger and Iceland Seas, 1990-2000, ICES Mar. Sc., 219, 329-332, 2003.

Olafsson, J., Olafsdottir, S. R., Benoit-Cattin, A., and Takahashi, T.: The Irminger Sea and the Iceland Sea time series measurements of sea water carbon and nutrient chemistry 1983-2006, Earth Syst. Sci. Data Discuss., 2, 477-492, 2009, http://www.earth-syst-sci-data-discuss.net/2/477/2009/.

Olafsson, J., Arnarson, T. S., Olafsdottir, S., and Danielsen, M.: Seasonal biogeochemical changes and air-sea $\mathrm{CO}_{2}$ flux in the Irminger and Iceland Seas, in preparation, 2009.

Olsen, A., Omar, A. M., Bellerby, R. G. J., Johannessen, T., Ninnemann, U., Brown, K. R., Olsson, K. A., Olafsson, J., Nondal, G., Kivimae, C., Kringstad, S., Neill, C., and Olafsdottir, S.: Magnitude and Origin of the Anthropogenic $\mathrm{CO}_{2}$ Increase and ${ }^{13} \mathrm{C}$ Suess Effect in the Nordic Seas Since 1981, Global Biogeochem. Cy., 20, GB3027, doi:10.1029/2005GB002669, 2006.

Orr, J. C., Fabry, V. J., Aumont, O., Bopp, L., Doney, S. C., Feely, R. A., Gnanadesikan, A., Gruber, N., Ishida, A., Joos, F., Key, R. M., Lindsay, K., Maier-Reimer, E., Matear, R., Monfray, P., Mouchet, A., Najjar, R. G., Plattner, G.-K., Rodgers, K. B., Sabine, C. L., Sarmiento, J. L., Schlitzer, R., Slater, R. D., Totterdell, I. J., Weirig, M.-F., Yamanaka, Y., and Yool, A.: Anthropogenic ocean acidification over the twenty-first century and its impact on calcifying organisms, Nature, 437, 681-686, 2005.

Royal Society: Ocean acidification due to incxreasing atmospheric carbon dioxide, Royal Society, London 12/05, 59, 2005.

Santana-Casiano, J. M., Gonzalez-Davila, M., Rueda, M.-J., Llinas, O., and Gonzalez-Davila, E.-F.: The interannual variability of oceanic $\mathrm{CO}_{2}$ parameters in the northeast Atlantic subtropical gyre at the ESTOC site, Global Biogeochem. Cy., 21, GB1015, doi:10.1029/2006GB002788, 2007.
Schlitzer, R.: Ocean Data View, http://odv.awi.de, 2009.

Schuster, U. and Watson, A. J.: A variable and decreasing sink for atmospheric $\mathrm{CO}_{2}$ in the North Atlantic, J. Geophys. Res., 112, C11006, doi:10.1029/2006JC003941, 2007.

Schuster, U., Watson, A. J., Bates, N. R., Corbiere, A., GonzalezDavila, M., Metzl, N., Pierrot, D., and Santana-Casiano, M.: Trends in North Atlantic sea-surface $\mathrm{fCO}_{2}$ from 1990 to 2006, Deep-Sea Res. Pt. II, 56, 620-629, 2009.

Skjelvan, I., Olsen, A., Anderson, L. G., Bellerby, R. G. J., Falck, E., Kasajima, Y., Kivimae, K., Omar, A., Rey, F., Olsson, K. A., Johannessen, T., and Heinze, C.: A review of the inorganic carbon cycle of the Nordic Seas and Barents Sea, in: The Nordic Seas: An Integrated Perspective, edited by: Drange, H., Dokken, T., Furevik, T., Gerdes, R., and Berger, W., Geophysical Monograph Series, American Geophysical Union, Washington DC, 157-175, 2005.

Stefánsson, U.: North Icelandic Waters, Rit Fiskideildar, 3, 1-269, 1962.

Steinacher, M., Joos, F., Frölicher, T. L., Plattner, G.-K., and Doney, S. C.: Imminent ocean acidification in the Arctic projected with the NCAR global coupled carbon cycle-climate model, Biogeosciences, 6, 515-533, 2009, http://www.biogeosciences.net/6/515/2009/.

Swift, J. H., Aagaard, K., and Malmberg, S.-A.: The contribution of the Denmark Strait overflow to the deep North Atlantic, DeepSea Res., 27A, 29-42, 1980.

Takahashi, T., Ólafsson, J. , Broecker, W. S., Goddard, J., Chipman, D. W., and White, J.: Seasonal variability of the carbonnutrient chemistry in the ocean areas west and north of Iceland, Rit Fiskideildar, 9, 20-36, 1985.

Takahashi, T., Ólafsson, J., Goddard, J. G., Chipman, D. W., and Sutherland, S. C.: Seasonal variation of $\mathrm{CO} 2$ and nutrient salts over the high latitude oceans: A comparative study, Global Biogeochem. Cy., 7, 843-878, 1993.

Takahashi, T., Sutherland, S. C., Sweeney, C., Poisson, A., Metzl, N., Tilbrook, T., Bates, N., Wanninkhof, R., Feely, R. A., Sabine, C., Olafsson, J., and Nojiri, Y.: Global sea-air CO2 flux based on climatological suface ocean pCO2, and seasonal biological and temperature effects, Deep-Sea Res. Pt. II, 49, 1601-1622, 2002.

Takahashi, T., Sutherland, S. C., Wanninkhof, R., Sweeney, C., Feely, R. A., Chipman, D. W., Hales, B., Friederich, G., Chavez, F., Sabine, C., Watson, A., Bakker, D. C. E., Schuster, U., Metzl, N., Yoshikawa-Inoue, H., Ishii, M., Midorikawa, T., Nojiri, Y., Körtzinger, A., Steinhoff, T., Hoppema, M., Olafsson, J., Arnarson, T. S., Tilbrook, B., Johannessen, T., Olsen, A., Bellerby, R., Wong, C. S., Delille, B., Bates, N. R., and Baar, H. J. W. d.: Climatological Mean and Decadal Change in Surface Ocean pCO2, and Net Sea-air CO2 Flux over the Global Oceans, Deep-Sea Res. Pt. II, 56, 554-557, doi:10.1016/j.dsr2.2008.12.009, 2009.

Weiss, R. F.: Carbon dioxide in water and seawater: The solubility of a non-ideal gas, Mar. Chem., 2, 203-215, 1974. 